\title{
Pemetaan Kawasan Strategis Nasional Borobudur
}

\author{
Yenny Supandi dan Joni Setiyawan \\ Balai Konservasi Borobudur \\ Email : yny_chris@yahoo.com
}

\begin{abstract}
Abstrak: Kompleks Candi Borobudur termasuk di dalamnya Candi Mendut, Candi Pawon dan kawasan di sekitarnya pada tahun 2008 telah ditetapkan menjadi Kawasan Strategis Nasional (KSN) melalui PP No. 26 Tahun 2008 tentang Rencana Tata Ruang Wilayah Nasional. Pengelolaan tata ruang. KSN Borobudur memerlukan data yang lengkap dan akurat supaya pemanfaatan ruangnya tidak melanggar peraturan yang telah ditetapkan. Salah satu langkah penting untuk mendukung upaya tersebut adalah pemetaan dan pengelolaan data KSN Borobudur yang mencakup area \pm 1337 Hektar.

Pemetaan KSN Borobudur ini ditujukan untuk menghasilkan peta penggunaan lahan dan peta dasar (berisi jaringan jalan, sungai, saluran irigasi, batas administrasi, dan garis kontur) skala 1:10.000. Citra penginderaan jauh (PJ) digunakan sebagai sumber data primer, Peta Rupa Bumi Indonesia (SBI) sebagai sumber data sekunder dan Sistem Informasi Geografis untuk pengolahan data. Citra satelit tahun 2008 diperoleh dengan cara capture dari Google Maps, kemudian direktifikasi menggunakan software ER Mapper. Citra Ikonos tahun 2003 berkoordinat dipakai sebagai referensi dalam rektifikasi. Citra terkoreksi diinterpretasi visual dengan metode on screen digitizing menggunakan software ArcView, dan Peta RBI sebagai referensi dalam interpretasi. Peta penggunaan lahan sementara diverifikasi di lapangan dengan metode purposive random sampling. Hasil verifikasi lapangan dipakai sebagai acuan uji ketelitian interpretasi, selanjutnya dilakukan reinterpretasi untuk menghasilkan peta penggunaan lahan.

Hasil capture citra PJ kualitasnya cukup bagus dan memungkinkan digunakan untuk interpretasi visual. Rektifikasi geometri menghasilkan citra bereferensi geografis yang baik ditandai dengan plot fitur topografis yang akurat secara spasial. Hasil interpretasi visual citra menghasilkan data yang akurat dengan tingkat ketelitian 91,54\%. Lima penggunaan lahan terluas di KSN Borobudur adalah sawah 445,557 Ha (32,93\%), kebun 327,13 Ha (24,18\%), permukiman 200,296 $\mathrm{Ha}(14,8 \%)$, tegalan $164,691 \mathrm{Ha}(12,17 \%)$ dan lahan terbuka $61,84 \mathrm{Ha}(4,57 \%)$. Wilayah yang berupa lahan budidaya tidak terbangun 77,84\% dan lahan terbangun 22,16\%. Perbandingan tersebut menunjukkan bahwa KSN Borobudur mempunyai pola perdesaan. Perubahan penggunaan lahan dari lahan tidak terbangun menjadi lahan terbangun banyak terjadi di KSN Borobudur, sehingga membutuhkan pengawasan dan pengendalian sesuai dengan undang-undang yang berlaku.
\end{abstract}

Kata Kunci : Kawasan Strategis Nasional Borobudur, pemetaan, penginderaan jauh, Sistem Informasi Geografis

Abstract: Borobudur Temple Compounds that includes Mendut Temple, Pawon Temple, and its surrounding has been designated as National Strategic Area by Presidential Regulation No. 26 Year 2008 regarding National Spatial Planning. The management of Borobudur National Strategic Area needs complete and accurate data for its spatial use so that it will be in accordance with the regulations. One of the important steps is to map and manage Borobudur Strategic Area which covers the area of \pm 1337 Ha.

Mapping for Borobudur Strategic Area is aimed to produce land use and base map (includes road line, river, irrigation, administration border and contour line) scale 1:10.000. Remote sensing imagery is used as primary data source, Indonesian Topographic Map as secondary data source and Geographic Information System in processing the data. 2008 satellite imagery is obtained by capturing from Google Maps, then rectified by ER Mapper software. 2003 IKONOS imagery is used as the reference for rectification. Corrected imagery is interpreted visually by on screen digitizing method using ArcView software, and Indonesian Topographic Map as reference for interpretation. Land use map is verified temporarily in the field using purposive random sampling method. The result of field verification is used as interpretation accuracy test reference, continued by reinterpretation in producing land use map.

The result of the capture from remote sensing imagery has good result and it is possible to be used for visual 
interpretation. Geometry rectification produces good geographic-referred imagery signified by spatially accurate topographic features plot. The result of visual imagery uses accurate data with the accuracy of $91,54 \%$. Five biggest land uses in Borobudur National Strategic Area are rice field 445,557 Ha (32,93\%), home farm 327,13 $\mathrm{Ha}(24,18 \%)$, settlement 200,296 Ha (14,8\%), moor 164,691 Ha (12,17\%) and open area 61,84 Ha (4,57\%). Non-developed cultivated area $77,84 \%$ and developed area $22,16 \%$. The comparison shows that Borobudur National Strategic Area has rural pattern. The shift in land use fromm non-developed to developed area has been happening in rapid growth at Borobudur National Strategic Area, so that monitoring and control are needed to be enforced in accordance with present laws.

Keywords: National Strategic Area, to map, remote sensing, Geographic Information System

\section{A. Pendahuluan}

Candi Borobudur dibangun pada sekitar abad VIII - IX M pada zaman keemasan Dinasti Syailendra (Roesmanto, 2011). Setelah berfungsi sekitar 2 abad, candi ini kemudian ditinggalkan oleh penganutnya dan ditemukan kembali pada tahun 1814. Sejak ditemukannya kembali, upaya pelestarian Candi Borobudur telah dimulai. Menurut Tanudirjo (2008), pada hakekatnya pelestarian kompleks Candi Borobudur merupakan upaya untuk mengembalikan kepada fungsinya semula (back to basic), dalam bentuk revitalisasi nilai-nilai penting warisan budaya agar dapat dirasakan manfaatnya oleh generasi masa kini maupun mendatang.

Kompleks Candi Borobudur (Borobudur Temple Compound) termasuk di dalamnya Candi Mendut dan Candi Pawon telah ditetapkan oleh UNESCO sebagai warisan budaya dunia (world heritage) pada tahun 1991 karena memiliki nilai-nilai universal luar biasa (outstanding universal value). Selanjutnya upaya pelestarian tidak hanya dilakukan pada Candi Borobudur saja tetapi juga meliputi kawasan di sekitarnya yang pada tahun 2008 telah ditetapkan menjadi Kawasan Strategis Nasional melalui Peraturan Pemerintah No. 26 Tahun 2008 tentang Rencana Tata Ruang Wilayah Nasional.

Penataan ruang Kawasan Candi Borobudur sebagai Kawasan Strategis Nasional diprioritaskan karena mempunyai pengaruh sangat penting secara nasional di bidang kebudayaan, terlebih sudah termasuk dalam warisan budaya dunia. Dalam pengelolaan tata ruang Kawasan Strategis Nasional Borobudur diperlukan data yang lengkap dan akurat supaya setiap pemanfaatan ruang di kawasan ini tidak melanggar peraturan-peraturan yang telah ditetapkan. Pemetaan dan pengelolaan data Kawasan Strategis Nasional Borobudur yang mencakup area lebih kurang 1337 hektar memerlukan metode dan teknik yang tepat supaya manajemen data dalam jumlah besar dapat dilakukan dengan mudah, efektif dan efisien.

Sistem Informasi Geografis (SIG) merupakan sarana pengkajian dan penyajian informasi data wilayah yang dewasa ini telah menjadi kebutuhan pokok dalam pengelolaan wilayah. Fasilitas manajemen data yang terdapat dalam SIG dapat sangat berguna dalam pengelolaan Kawasan Strategis Nasional Borobudur. Metode analisis data SIG memungkinkan digunakan untuk kegiatan pemetaan (mapping), monitoring, pengukuran (measuring), dan pemodelan (modeling). Masukan data/input data dalam pekerjaan pemetaan memegang peranan yang sangat penting karena akurasi dan validitas input data akan menentukan outputnya (Hardjo, 2005). Citra penginderaan jauh (citra satelit) skala rinci dapat dimanfaatkan untuk koleksi data dalam pemetaan KSN Borobudur mengingat luasnya area yang dipetakan. Dengan citra satelit pengumpulan data dapat dilakukan lebih cepat dan delineasi batas obyek dapat dilakukan dengan mudah (Sutanto, 1994).

\section{B. Tujuan Pemetaan}

Tujuan dari kegiatan ini adalah untuk mengetahui kondisi terkini kenampakan fisik di Kawasan Strategis Nasional Borobudur yang meliputi penggunaan lahan (landuse), jaringan jalan, jaringan hidrologi, dan garis kontur yang akan dijadikan peta dasar (base map) pemetaan kajian-kajian KSN selanjutnya.

\section{Daerah Pemetaan}

Wilayah yang akan dipetakan adalah Kawasan Strategis Nasional Borobudur yang batas delineasinya telah ditetapkan oleh Kementerian Pekerjaan Umum dengan luas sekitar 1337 Hektar. Kawasan Strategis Nasional Borobudur meliputi Kecamatan Borobudur (Desa Borobudur, Desa Wanurejo, Desa Wringinputih, Desa Karangrejo, Desa Tuksongo, Desa Ngargogondo, Desa Candirejo), Kecamatan Mungkid (Desa Rambeanak, Desa Pabelan, Desa Ngrajek, Desa Paremono, Desa Bojong, Kelurahan Mendut).

\section{Metode Pemetaan}

Metodologi yang dipakai dalam pemetaan ini adalah:

1. Studi literatur.

2. Pengolahan data.

3. Analisis hasil pengolahan data. 


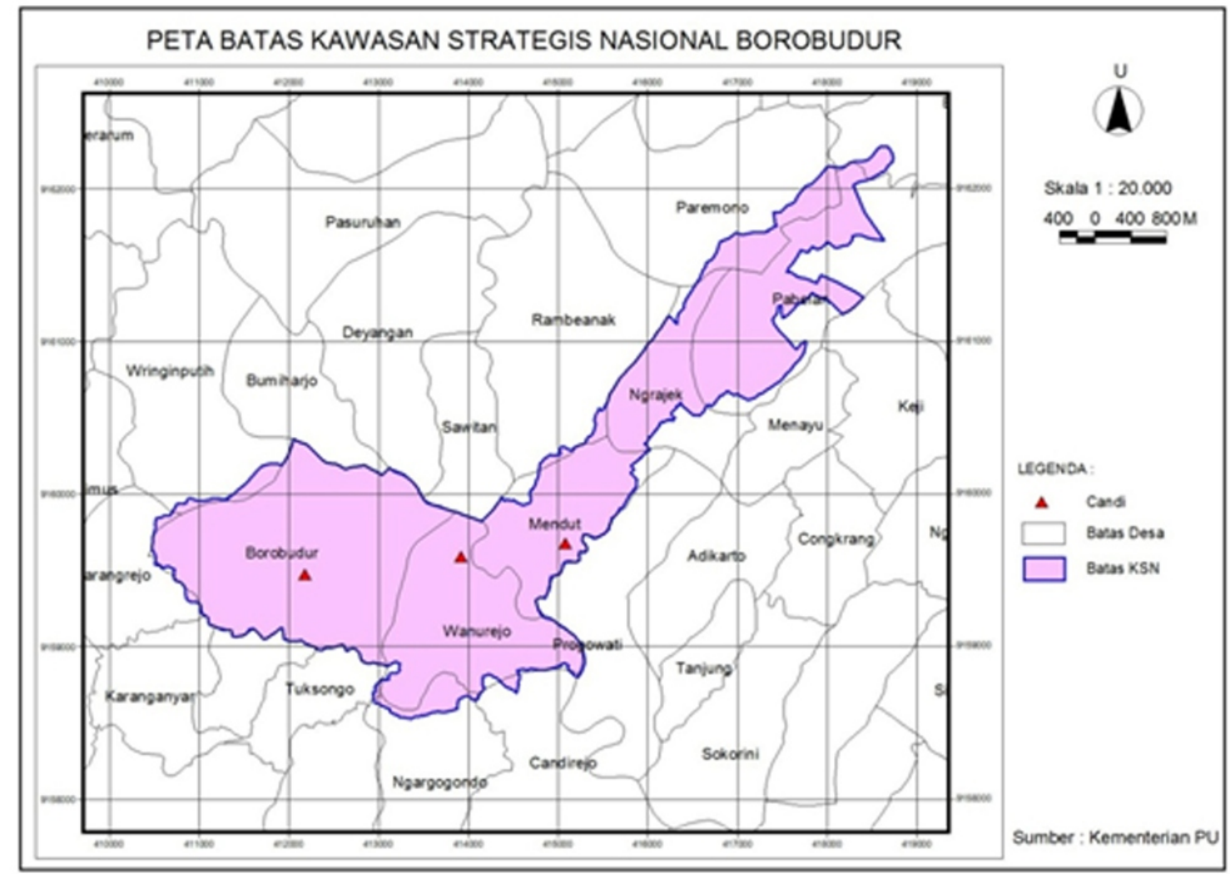

Gambar 1. Batas daerah pemetaan

4. Penarikan kesimpulan serta saran-saran untuk pemetaan lebih lanjut.

Secara umum metode pengolahan data citra sampai diperoleh hasil dan kesimpulan ditunjukkan pada diagram alir dibawah.

Data primer yang dipakai pada pemetaan ini adalah Citra IKONOS tahun 2008 hasil "capture" dari Google Maps

Kegiatan pemetaan Kawasan Strategis Nasional Borobudur ini dilaksanakan melalui beberapa tahap pelaksanaan yang dapat diurutkan sebagai berikut:

1. Pemotongan (cropping) dan pembuatan mosaik citra satelit sesuai daerah yang akan dipetakan dengan menggunakan software Adobe Photoshop.

2. Koreksi geometrik citra satelit menggunakan software ER Mapper dengan referensi koordinat menggunakan citra satelit Quickbird tahun 2003 yang telah mempunyai koordinat UTM.

3. Digitasi layer dan interpretasi penggunaan lahan pada citra satelit IKONOS tahun 2008 yang telah terkoreksi secara geometrik dengan menggunakan software ArcView.

4. Mencetak peta sementara hasil interpretasi.

5. Survei lapangan untuk mendapat data kondisi eksisting dari penggunaan lahan dan cek kebenaran hasil interpretasi.

6. Reinterpretasi peta sementara dengan menambahkan data yang diperoleh dari hasil survei lapangan.

7. Pembuatan layout akhir peta Kawasan Strategis Nasional Borobudur

8. Penulisan laporan hasil studi.

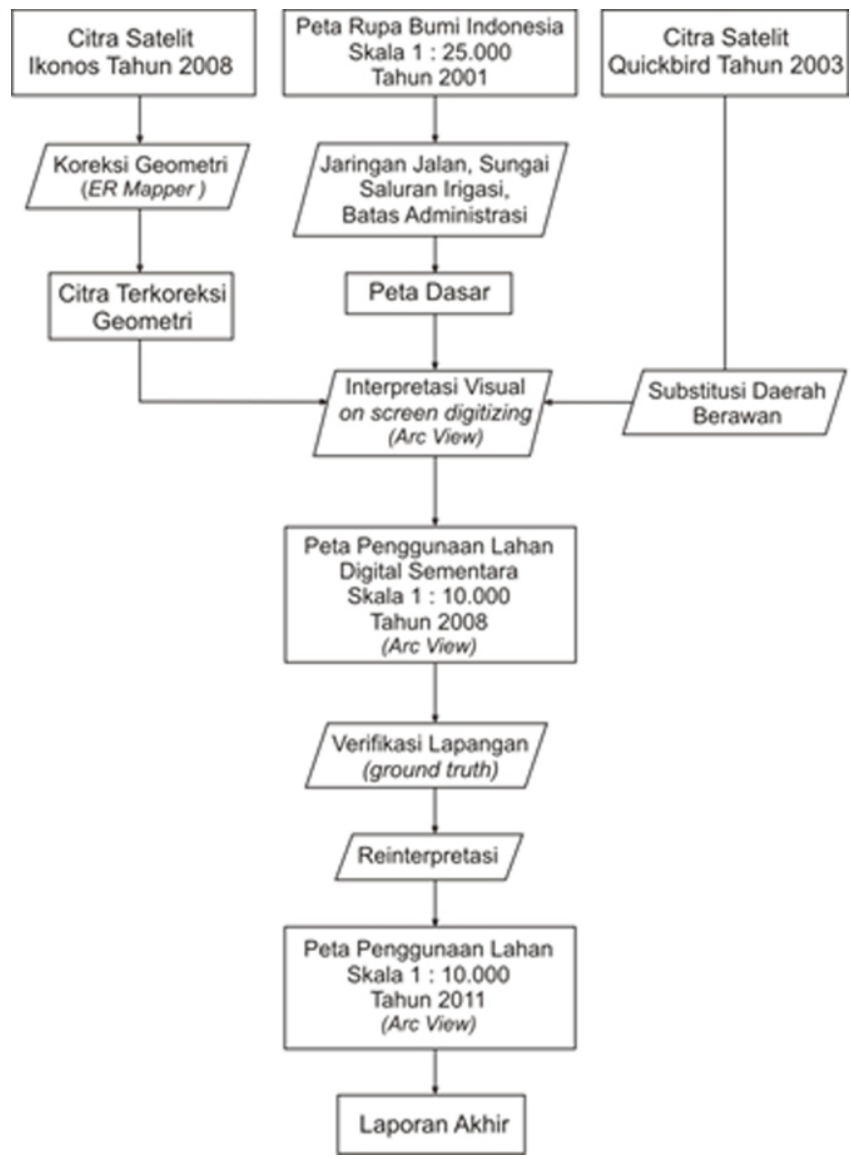

Gambar 2 : Skema Pemetaan

\section{E. Hasil dan Pembahasan}

Pengambilan Citra (capture) dari Google maps

Citra satelit kawasan Borobudur diperoleh dengan cara "capture" atau merekam tampilan layar monitor dari Google Maps. "Capture" dilakukan menggunakan laman Firefox, yang dilengkapi dengan "add on" yang memiliki 


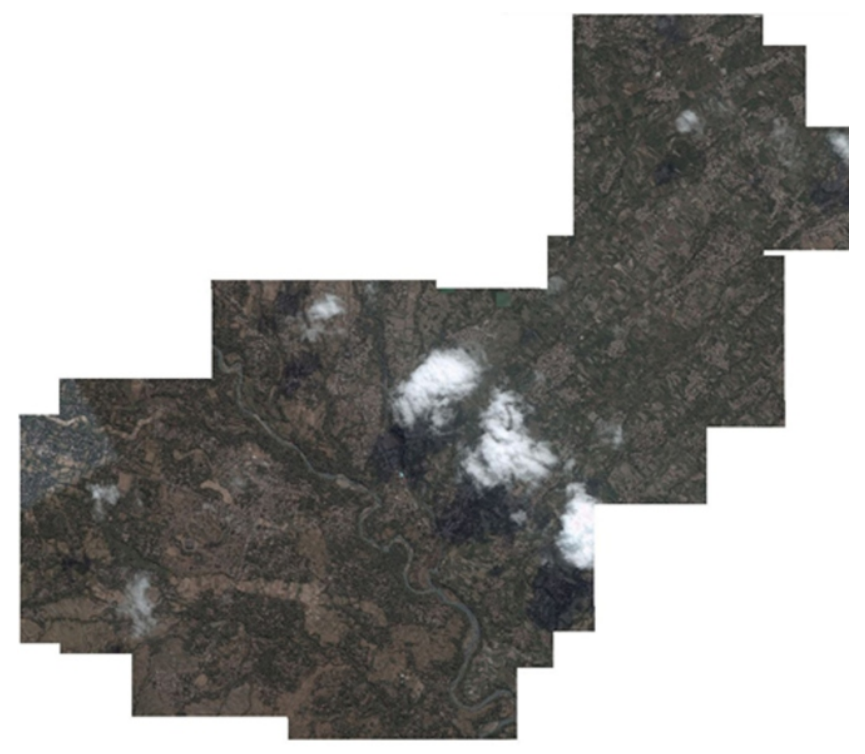

Gambar 3. Mosaik citra hasil "capture"

kemampuan untuk merekam seluruh halaman di layar browser yang diberi nama Screengrab. Capture citra menggunakan metode ini memungkinkan pengambilan gambar untuk wilayah yang luas dengan resolusi yang bagus dengan sekali proses. Namun karena keterbatasan bandwidth maka capture dilakukan dalam bentuk potongan-potongan daerah penelitian yang kemudian dimosaik dengan Photoshop. Mosaic citra hasil capture dari Google Maps dapat ditunjukkan dengan Gambar 3.

\section{Rektifikasi (Koreksi Geometrik)}

Rektifikasi dilakukan menggunakan metode Image to Image Rectification dengan citra Quickbird tahun 2003 sebagai referensi Gambaran proses rektifikasi image to image seperti pada gambar 4 .

Hasil koreksi geometrik pada pemetaan ini sangat bagus untuk area Candi Borobudur dan sekitarnya (titik GCP 1, 2, 3, 4, 5, 6, 7, 13, 15) sedangkan untuk sepanjang koridor Palbapang nilai RMSe cukup besar. Pemilihan GCP sudah mempertimbangkan penempatan posisi GCP dengan cermat, jumlah memadai dan distribusi yang merata, tetapi pada beberapa titik, nilai RMSe masih relatif besar, namun yang lebih penting adalah plot fitur topografis lebih akurat secara spasial (karena dalam perhitungan RMSe software tidak memperhitungkan jumlah GCP dan distribusi spasialnya) (Danoedoro, 1996). Hal ini kemungkinan disebabkan pada saat pembuatan mosaik citra dari potongan citra hasil capture agak bergeser, namun pergeseran koordinat kurang dari ukuran satu piksel (resolusi Citra Ikonos 1 Meter) sehingga hasil koreksi geometri ini dianggap cukup memadai.
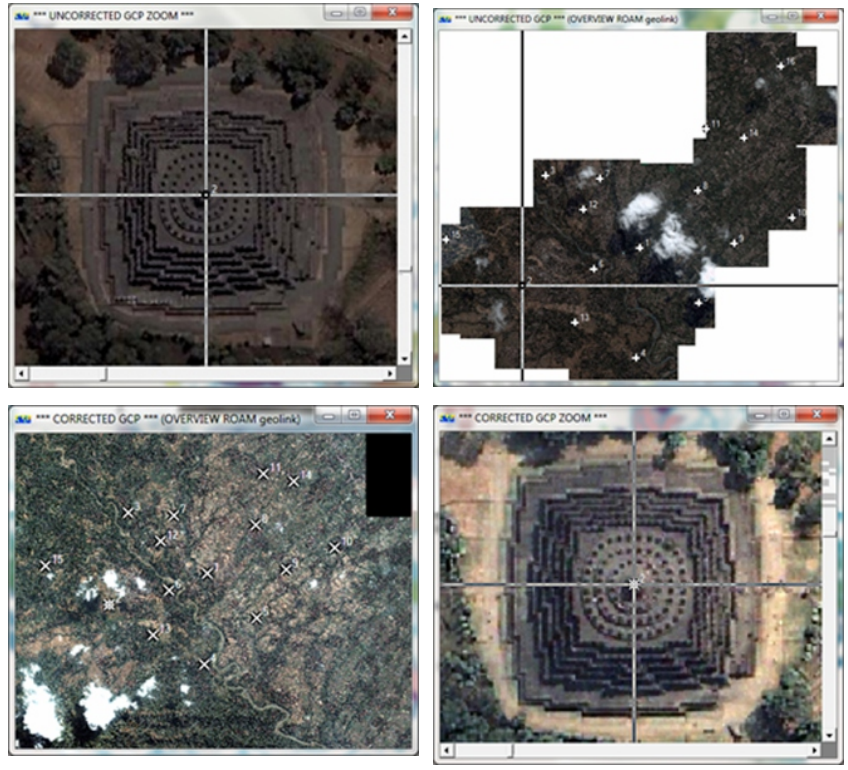

Gambar 4. Rektifikasi Citra dengan Metode "Image to Image Rectification"

Interpretasi Visual pada Citra Satelit

Identifikasi dan pengenalan obyek pada citra dilakukan secara visual dengan cara on screen digitizing menggunakan perangkat lunak ArcView. Proses identifikasi dan pengenalan karakteristik obyek dilakukan dengan menerapkan unsur-unsur interpretasi citra dan tidak kalah pentingnya adalah pengetahuan interpreter mengenai wilayah yang dipetakan (local knowledge). Interpreter yang mempunyai local knowledge bagus relatif lebih mudah mengenali obyek yang tergambar pada citra dan ketelitian hasil interpretasinya pun biasanya lebih baik daripada interpreter yang tidak mempunyai pengetahuan tentang wilayah pemetaan (Sutanto, 1994). Klasifikasi penggunaan lahan yang digunakan pada pemetaan ini adalah klasifikasi menurut Peraturan Menteri Negara Agraria Nomor 1 Tahun 1997 dengan modifikasi tentang Pemetaan Penggunaan Tanah Pedesaan.

Identifikasi dan pengenalan karakteristik obyek pada citra sampai pada kesimpulan penggunaan lahannya adalah sebagai berikut:

1. Jalan

Obyek jalan sangat mudah dikenali pada citra dengan bentuk memanjang, relatif lurus, warna abuabu, rona cerah, berasosiasi dengan permukiman, dan antar ruas jalan saling terhubung. Jalan utama (jalan aspal, jalan kabupaten, jalan desa) yang ukurannya relatif lebar sangat mudah dikenali sehingga delineasinya mudah dilakukan, tetapi untuk jalan kampung/gang agak sulit dikenali karena berada di dalam permukiman, tertutup atap bangunan dan pepohonan. Dalam hal ini local knowledge menjadi bagian sangat penting dalam melakukan delineasi. Klasifikasi jalan dilakukan dengan menggunakan referensi Peta Rupa Bumi Indonesia. 


\section{Sungai}

Pada citra, sungai besar tampak jelas dengan ukuran yang lebar, berkelok-kelok, tidak beraturan, berasosiasi dengan sawah, tegalan, jembatan. Di bagian tengah berwarna abu-abu, rona cerah keabuan (rona air), sedangkan di bagian tepi rona cerah kecoklatan (dataran banjir), tanpa vegetasi. Di kanan kiri sungai besar biasanya terdapat kebun campuran yang ditandai dengan vegetasi yang cukup lebat.

Anak sungai tampak dengan bentuk yang memanjang, berkelok-kelok, tak beraturan, kanan kirinya ditumbuhi vegetasi yang cukup rapat. Wilayah KSN dilewati dua sungai besar yaitu Sungai Progo dan Elo.

Saluran irigasi yang bertalud semen biasanya tampak jelas pada citra, sedangkan saluran irigasi tanpa talud semen biasanya tidak tampak jelas, sehingga datanya diambil pada saat cek lapangan.

\section{Permukiman}

Permukiman adalah sekumpulan bangunan yang digunakan untuk tempat tinggal. Pola permukiman perdesaan biasanya tidak teratur baik bentuk, ukuran maupun persebaran spasialnya. Jarak antar rumah tidak seragam dan membentuk jaringan jalan tidak teratur. Permukiman dapat dikenali dengan baik pada citra dari bentuk atap rumah yang biasanya persegi panjang, bergerombol dengan vegetasi (pekarangan) di sekitarnya. Warna abu-abu/coklat, rona cerah sampai sedang, tekstur kasar dan berasosiasi dengan jalan. Luas permukiman adalah 200,296 Hektar atau 14,80\%.

4. Kantor

Perkantoran adalah bangunan yang digunakan untuk urusan administrasi umum dan pemerintahan. Yang termasuk dalam kategori kantor antara lain kantor desa, kantor kecamatan, puskesmas, Kantor Dinas Kesehatan (GAKI), BKP Borobudur, Kantor Dinas Perikanan, Kantor Polisi, Kantor Pos, dan Kantor Urusan Agama. Bangunan kantor dikenali dari bentuk, warna dan rona yang relatif sama dengan rumah, namun biasanya kantor berukuran lebih besar dibandingkan rumah tinggal, mempunyai halaman terbuka, terletak di tepi jalan besar. Di daerah pariwisata seperti di sekitar Candi Borobudur, identifikasi kantor seringkali rancu dengan penginapan (homestay) dan hotel kecil. Dalam hal ini local knowledge memegang peranan penting dalam penarikan kesimpulan.

\section{Sekolah}

Sekolah dikenali dari bentuk bangunannya yang biasanya seperti huruf U, L, atau T. Ukurannya relatif besar dibandingkan rumah tinggal, mempunyai halaman dan menghadap ke jalan. Beberapa sekolah juga berasosiasi dengan lapangan olahraga. Sekolah PAUD dan Taman Kanak-kanak biasanya berukuran kecil dan mempunyai karakteristik yang sama dengan rumah tinggal, sehingga diperlukan local knowledge yang baik dalam interpretasinya. Sekolah muslim/pondok pesantren biasanya berasosiasi dengan masjid.

6. Perdagangan dan Jasa

Yang termasuk dalam klasifikasi perdagangan dan jasa adalah toko, warung, rumah makan, restoran, homestay, hotel, dan kantor swasta. Toko (kios), warung, rumah makan, restoran, kantor swasta biasanya mempunyai karakteristik sama dengan rumah tinggal, sedangkan homestay dan hotel mempunyai ukuran lebih besar. Perdagangan dan jasa biasanya terletak di tepi jalan besar dan aksesnya mudah. Kios biasanya berasosiasi dengan pasar. Di wilayah pemetaan terdapat hotel besar yang dengan mudah diidentifikasi, yaitu Pondok Tingal dan Hotel Manohara. Hotel yang belum ada saat perekaman namun sudah ada pada saat survei adalah Hotel Plataran di Desa Borobudur, Hotel Saraswati di Desa Wanurejo, dan dua homestay di Desa Wanurejo. Perdagangan dan jasa di kawasan strategis nasional Borobudur seluas 42 Hektar atau 3,11\%.

7. Wihara, Masjid, Gereja

Wihara biasanya merupakan sebuah kompleks bangunan yang terdiri dari bangunan utama dengan ukuran besar dan bangunan kecil di sekitarnya. Biasanya kompleks wihara berukuran besar dan bentuk bangunannya unik (berbeda dengan rumah tinggal biasa). Di dalam kawasan strategis nasional Borobudur terdapat empat wihara yang secara administratif masuk di Desa Mendut, Desa Borobudur, dan Desa Wanurejo.

Masjid mempunyai ciri khusus yaitu atap berbentuk bujursangkar, umumnya terdapat kubah dari logam yang berbentuk bulat dan ujungnya lancip. Pada citra, atap masjid mudah dikenali terutama pada masjid yang berukuran besar. Namun terkadang atap masjid agak mirip dengan rumah joglo yang atapnya berbentuk bujursangkar dan lancip bangan tengahnya. Demikian juga gereja, seringkali bentuk atapnya mirip dengan atap masjid, sehingga local knowledge memegang peranan penting dalam interpretasinya. Di Kawasan Strategis Nasional terdapat dua gereja di Desa Borobudur dan Desa Mendut, sedangkan masjid ada hampir di setiap dusun.

8. Sawah Irigasi dan Tegalan

Sawah irigasi menurut definisi dari Departemen Pertanian adalah lahan usaha tani yang secara fisik permukaan tanahnya rata, dibatasi pematang, dapat ditanami padi/palawija/tanaman pangan lainnya yang 
sumber air utamanya berasal dari air irigasi. Pada citra, sawah irigasi berbentuk petak-petak yang terbentuk dari garis pematang dan terdapat pola kelurusan yang biasanya saluran irigasi. Tekstur halus sampai agak halus, berwarna hijau tua, hijau muda, hijau keabu-abuan dan coklat. Sawah irigasi berasosiasi dengan sungai sebagai sumber pengairan.

Tegalan adalah sebidang tanah yang dimanfaatkan untuk pertanian lahan kering antara lain padi gogo dan palawija. Pada citra, tegalan berbentuk petak-petak yang terbentuk oleh pematang, dengan ukuran yang biasanya lebih kecil daripada sawah irigasi. Tekstur kasar, warna dominan coklat kehijauan (pantulan tanah kering tertutup vegetasi jarang). Meskipun kadang tegalan berada di dekat sungai, namun pengairannya tidak berasal dari sungai tersebut karena posisi tegalan lebih tinggi daripada sungai, sehingga pengairannya mengandalkan air hujan.

9. Kebun campuran, Pekarangan, Hutan buatan

Kebun campuran adalah lahan yang ditanami dengan berbagai macam tanaman tahunan seperti petai, melinjo, buah-buahan, kayu-kayuan, dan sebagainya. Kebun campuran biasanya terletak di sepanjang sempadan sungai dekat permukiman dan sawah, karena selain bertujuan ekonomis juga berfungsi sebagai pengendali erosi, mitigasi banjir dan mempertahankan keanekaragaman hayati. Pada citra, kebun campuran tampak sebagai bentuk kanopi pohon yang bergerombol dengan pola tidak teratur, berwarna hijau tua dengan tekstur sedang sampai kasar.

Pekarangan adalah sebidang tanah darat (mencakup kolam) yang terletak langsung di sekeliling rumah dengan batas-batas yang jelas (berpagar atau tidak berpagar), ditanami dengan berbagai jenis tanaman dan masih memiliki hubungan kepemilikan dengan penghuninya. Di daerah perdesaan umumnya setiap rumah memiliki pekarangan yang cukup luas dan sering berbatasan langsung dengan kebun campuran. Pekarangan tampak sebagai kanopi pohon, bergerombol tidak teratur, berwarna hijau untuk tutupan vegetasi lebat dan coklat kehijauan untuk vegetasi jarang. Tekstur kasar karena jenis, ukuran dan warna tanaman yang heterogen.

Hutan buatan adalah hutan yang sengaja ditanam, biasanya memiliki karakteristik tanaman yang homogen baik jenis tanaman, umur, maupun metode penanamannya. Di kawasan strategis nasional hutan buatan terdapat di kawasan bukit Dagi, sebelah barat laut Candi Borobudur. Hutan buatan ini tampak lebat dengan vegetasi yang relatif homogen.

\section{Makam}

Pada citra, makam dapat dikenali dari bentuk cungkup yang hampir sama dengan bentuk rumah tinggal namun ukurannya lebih kecil. Batu nisan biasanya menimbulkan tekstur kasar, warna kecoklatan, rona sedang dan tutupan vegetasi pada makam biasanya jarang. Makam yang berukuran kecil kadang sulit diidentifikasi karena sering tertutup vegetasi di sekitarnya dan sulit dibedakan dengan pekarangan atau tegalan.

\section{Pasar, Terminal}

Pasar dapat dikenali dari ukuran bangunannya yang besar, bentuk atap seragam dan memanjang, ukuran atap sama dan pola teratur. Tekstur kasar dan warna abuabu cerah. Pasar biasanya terletak di pusat kota, di tepi jalan besar, beasosiasi dengan permukiman padat dan kios-kios. Di kawasan strategis nasional Borobudur, selain terdapat pasar biasa terdapat juga pasar ikan di Desa Ngrajek tepi jalan raya Borobudur. Pasar ikan tersebut cukup besar karena Desa Ngrajek merupakan sentra budidaya ikan air tawar di Kabupaten Magelang.

Terminal dapat dikenali dari ukurannya yang relatif luas dan keberadaan kendaraan roda empat yang menjadi moda transportasi umum di daerah penelitian. Jalan aspal berwarna abu-abu gelap, bangunan berwarna abu-abu cerah, tekstur halus sampai sedang. Terminal selalu berasosiasi dengan jalan besar.

12. Lahan Terbuka, Tutupan Vegetasi Hijau, dan Lapangan Olah Raga

Lahan terbuka merupakan lahan yang tidak bervegetasi atau hamparan tanah kering yang kadangkadang hanya ditumbuhi rumput tipis atau vegetasi sangat jarang. Pada citra, lahan terbuka tampak dengan warna coklat, tekstur halus sampai sedang, dan rona cerah. Lahan terbuka yang ditutupi rumput akan tampak hijau pada musim hujan, dan coklat (kering) pada musim kemarau. Tutupan vegetasi hijau merupakan lahan yang ditumbuhi tanaman tahunan, yang ditanam dengan maksud penghijauan, bukan sebagai tanaman produksi. Tutupan vegetasi hijau tampak berwarna hijau tua, rona gelap, berbentuk kanopi pohon yang bergerombol dengan tekstur kasar.

Lapangan olah raga tampak dari bentuk persegi panjang, berupa hamparan tanah kering, berwarna coklat, tekstur halus dan rona cerah. Lapangan olah raga dapat berupa lapangan sepak bola, lapangan tenis, dan kolam renang. Karakteristik kolam renang sangat berbeda dengan lapangan bola dan lapangan tenis karena perbedaan materi pembentuknya. Seperti pada foto biasa, kolam renang tampak berwarna biru, rona cerah, dan tekstur halus. 


\section{Kolam air tawar (kolam ikan)}

Kolam air tawar dikenali dengan bentuk (umumnya) persegi panjang, rona gelap, warna hijau keabuan. Kolam air tawar yang dibuat dalam skala besar, misalnya oleh Balai Pembenihan Ikan, biasanya berupa betak-petak yang dibatasi pematang dari semen dan berukuran cukup lebar, sehingga lebih mudah dibedakan dengan sawah irigasi. Kolam air tawar yang berisi air cukup banyak lebih mudah dibedakan dengan sawah irigasi daripada kolam kering (habis dipanen) karena air keruh memberi rona lebih gelap dan tekstur lebih halus. Kolam kering sangat sulit dibedakan dengan sawah bero, sehingga cek lapangan sangat penting untuk koreksi interpretasinya. Kolam air tawar banyak terdapat di Desa Ngrajek yang merupakan sentra budidaya ikan air tawar di Kabupaten Magelang.

\section{Verifikasi Lapangan (Ground Check)}

Verifikasi lapangan dilakukan pada Peta Penggunaan Lahan Sementara untuk melihat kebenaran dan ketelitian hasil interpretasi visual di lapangan. Verifikasi lapangan juga dimanfaatkan untuk mengambil data yang tidak diperoleh dari citra, misalnya jalan baru yang belum ada pada citra, jalan kampung/gang yang tidak tampak pada citra karena tertutup vegetasi, anak sungai atau saluran irigasi yang tidak teridentifikasi karena tertutup vegetasi.

Mempertimbangkan keterbatasan waktu, biaya, kondisi lapangan dan tujuan pemetaan maka verifikasi dilakukan dengan metode purposive random sampling yaitu pemilihan sampel secara acak tetapi dengan pertimbangan tertentu. Jumlah sampel yang diambil sebanyak 130 sampel dengan persebaran proporsional pada setiap grid peta.

Perhitungan ketelitian interpretasi berdasarkan Matriks Uji Ketelitian Hasil Interpretasi adalah sebagai berikut:

Tingkat ketelitian $=$

$$
\frac{\text { Jumlah sampel yang betul }}{\text { Jumlah seluruh sampel }} \times 100 \%
$$

$\underline{20+4+4+14+11+14+2+4+1+9+12+5+1+2+1+1+6+1+1+1+1+1+2+1} \times 100 \%$ 130

$$
=91,54 \%
$$

Hasil perhitungan ketelitian interpretasi $91,54 \%$ menunjukkan bahwa hasil interpretasi yang dilakukan pada pemetaan ini adalah baik ( $\geq 85 \%$ ), berarti data hasil penelitian layak digunakan untuk penelitian lebih lanjut.

\section{Reinterpretasi Citra}

Pada proses reinterpretasi dapat disimpulkan bahwa kesalahan interpretasi terjadi karena:

1. Citra yang digunakan adalah citra hasil perekaman tahun 2008, sedangkan interpretasi dan cek lapangan dilakukan tahun 2011 sehingga selama kurun waktu 3 tahun terjadi perubahan penggunaan lahan. Misalnya dari sawah menjadi permukiman, pekarangan menjadi permukiman.

2. Kemiripan atau kesamaan karakteristik obyek, misalnya bangunan rumah tinggal (permukiman) dengan warung atau toko (perdagangan dan jasa), sawah bero dengan kolamikan.

3. Fungsi ganda, yaitu pemanfaatan obyek untuk lebih dari satu fungsi, misalnya rumah dan warung.

Perubahan penggunaan lahan paling banyak ditemukan di sepanjang Jalan Raya Borobudur (Mendut Palbapang) yaitu perubahan dari sawah irigasi menjadi sarana perdagangan dan jasa (warung/toko/restoran), sawah irigasi menjadi rumah tinggal baru, dan sawah menjadi kolam ikan. Perubahan dari sawah irigasi menjadi warung/toko/restoran ditengarai disebabkan oleh meningkatnya pariwisata ke Candi Borobudur, sehingga bisnis pendukung pariwisata juga ikut berkembang. Perubahan dari sawah irigasi menjadi permukiman disebabkan oleh meningkatnya aktifitas perekonomian dan kemudahan aksesibilitas di sepanjang Jalan Raya Borobudur. Perubahan dari sawah irigasi menjadi kolam ikan banyak terjadi di Desa Ngrajek dan sekitarnya, hal ini disebabkan peningkatan bisnis budidaya ikan, sehingga banyak petani yang menggunakan lahan pertaniannya untuk beternak ikan.

Perubahan penggunaan lahan di desa-desa sekitar Candi Borobudur pada umumnya dari pekarangan, sawah dan tegalan menjadi permukiman (rumah tinggal). Perubahan dari pekarangan menjadi hotel (di Desa Wanurejo), sawah irigasi menjadi hotel (di Desa Wanurejo). Perubahan penggunaan lahan dari sawah, tegalan, pekarangan menjadi rumah tinggal biasanya tidak menimbulkan efek yang mencolok secara visual pada kawasan yang dipetakan, karena rumah tinggal biasanya berukuran relatif kecil. Perubahan yang menimbulkan efek mencolok secara visual adalah keberadaan hotel dan homestay baru, karena biasanya hotel dan homestay berukuran relatif besar dan hotel-hotel baru memiliki arsitektur yang unik. Perubahan penggunaan lahan yang cukup mencolok terjadi di sepanjang jalan yang berhadapan langsung dengan pintu masuk parkir Candi Borobudur. Pertumbuhan kios parkir dan warung makan cukup pesat, namun kenampakan bangunan tidak rapi, 


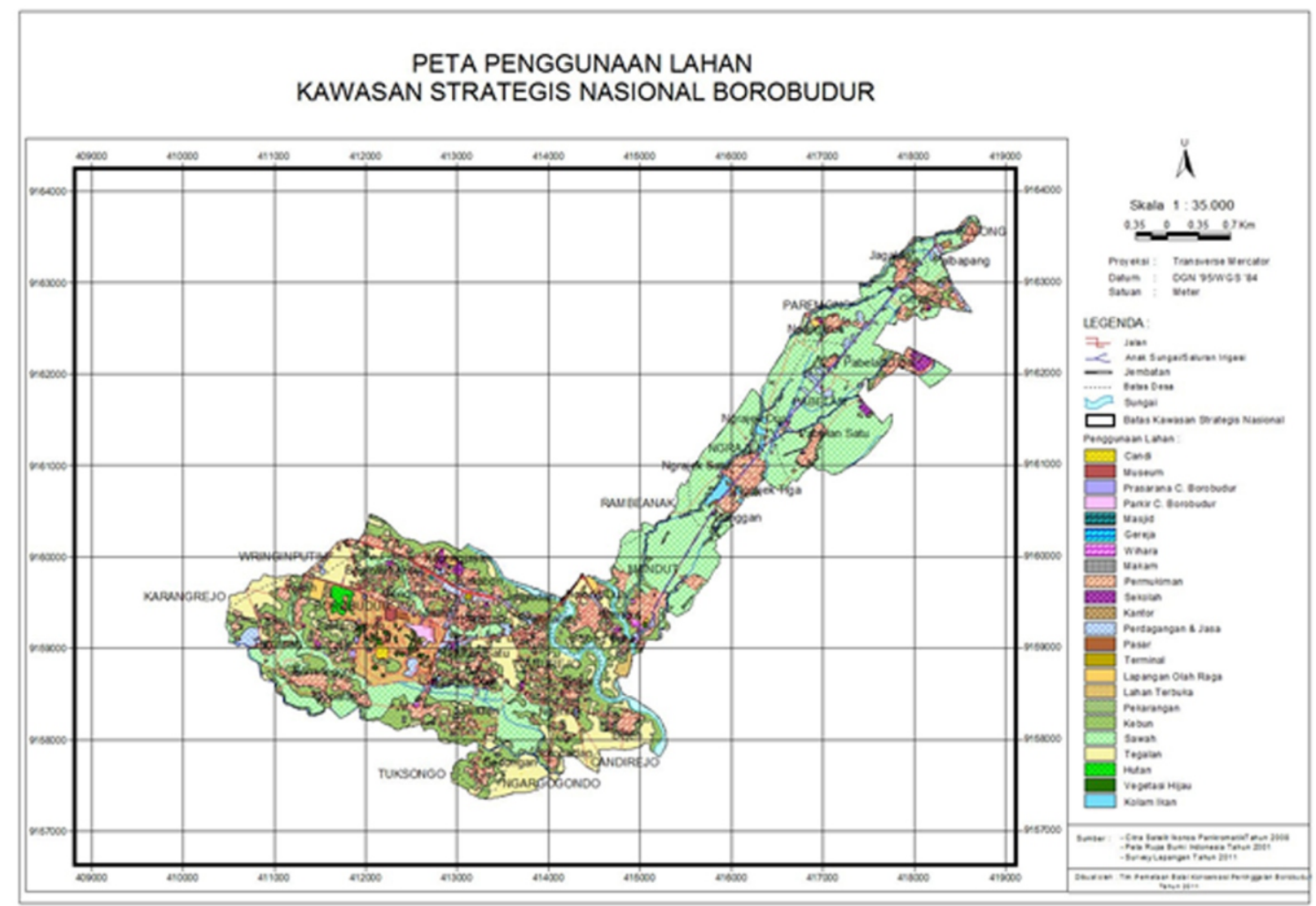

Gambar 5. Peta penggunaan Lahan Kawasan Strategis Nasional Borobudur

karena hanya berupa bangunan setengah permanen dan justru menimbulkan kesan kumuh.

F. Analisis Penggunaan Lahan dalam Kawasan Strategis Nasional Borobudur

Lima penggunaan lahan terluas di Kawasan Strategis Nasional Borobudur adalah sawah seluas 445,557 Hektar atau 32,93\%, diikuti kebun 327,13 Hektar atau $24,18 \%$, permukiman 200,296 Hektar atau 14,8 \%, tegalan 164,691 Hektar atau $12,17 \%$ dan lahan terbuka 61,84 Hektar atau 4,57\%. Kawasan Strategis Nasional Borobudur yang berupa lahan budidaya tidak terbangun sebanyak $77,84 \%$ dan lahan terbangun sebanyak $22,16 \%$. Perbandingan tersebut menunjukkan bahwa Kawasan Strategis Nasional Borobudur mempunyai pola perdesaan yang lahan pertaniannya jauh lebih luas dibanding dengan lahan terbangun. Tabel 1 menunjukkan luas setiap penggunaan lahan di kawasan strategis nasional Borobudur.

Hasil pemetaan ini menunjukkan terdapat cukup banyak perubahan pemanfaatan lahan perdesaan dan lahan produktif menjadi lahan terbangun untuk tujuan komersial. Apabila perubahan ini terjadi terus menerus tanpa pengendalian, maka dalam waktu relatif singkat kawasan Borobudur akan kehilangan ciri khasnya yang berupa lahan pertanian produktif dan pola-pola permukiman desa menjadi kawasan padat yang mengarah pada pola perkotaan. Hal tersebut bertolak belakang
Tabel 1. Luas Penggunaan Lahan di KSN Borobudur

\begin{tabular}{|c|c|c|}
\hline Penggunaan Lahan & Luas (Hektar) & Persentase (\%) \\
\hline Sawah & 445,557 & 32,93 \\
\hline Kebun & 327,13 & 24,18 \\
\hline Permukiman & 200,296 & 14,81 \\
\hline Tegalan & 164,691 & 12,17 \\
\hline Lahan terbuka & 61,84 & 4,57 \\
\hline Perdagangan \& Jasa & 42,077 & 3,11 \\
\hline Sungai besar & 22,154 & 1,64 \\
\hline Sekolah & 12,654 & 0,94 \\
\hline Jalan & 12,18 & 0,90 \\
\hline Kolam ikan & 10,342 & 0,76 \\
\hline Pekarangan & 8,003 & 0,59 \\
\hline Tutupan vegetasi hijau & 7,869 & 0,58 \\
\hline Lapangan olah raga & 7,555 & 0,56 \\
\hline Kantor & 6,74 & 0,50 \\
\hline Hutan & 5,469 & 0,40 \\
\hline Parkir Candi Borobudur & 4,035 & 0,30 \\
\hline Makam & 2,43 & 0,18 \\
\hline Candi & 2,066 & 0,15 \\
\hline Masjid & 1,974 & 0,15 \\
\hline Museum & 1,844 & 0,14 \\
\hline Prasarana Candi Borobudur & 1,812 & 0,13 \\
\hline Wihara & 1,761 & 0,13 \\
\hline Pasar & 1,441 & 0,11 \\
\hline Terminal & 0,48 & 0,04 \\
\hline Gereja & 0,434 & 0,03 \\
\hline
\end{tabular}

dengan strategi pelestarian dan fungsi lindung lingkungan yang terdapat dalam UU RI Nomor 26 Tahun 2007 tentang Penataan Ruang dan Peraturan Pemerintah Republik Indonesia Nomor 26 Tahun 2008, yang mengharuskan pembatasan pengembangan prasarana dan sarana di dalam dan di sekitar kawasan strategis nasional yang dapat memicu perkembangan budidaya dan mengembangkan kegiatan budidaya tidak terbangun di sekitar kawasan strategis nasional yang berfungsi sebagai 
zona penyangga yang memisahkan kawasan lindung dengan kawasan budidaya terbangun.

Pengelolaan penggunaan lahan di Kawasan Strategis Nasional Borobudur dapat dilakukan dengan optimal apabila kondisi lingkungan awal sebagai basis data diketahui secara detail sehingga dapat dibuat perencanaan pemanfaatan ruang dengan tepat. Setelah penyusunan basis data dan perencanaan fungsi ruang, dalam pengelolaan penggunaan lahan diperlukan monitoring (pengawasan) pemanfaatan lahan dalam rangka pengendalian perubahan fungsi lahan. Dalam monitoring pemanfaatan lahan perlu dilakukan pemetaan penggunaan lahan secara periodik supaya dapat diketahui tren perubahan penggunaan lahan dan dapat diketahui apakah regulasi tentang penataan ruang telah dipatuhi dan dilaksanakan oleh berbagai pihak yang terkait.

G. Kesimpulan

1. Teknologi penginderaan jauh dan Sistem Informasi Geografis sangat berguna dalam pemetaan tematik kawasan yang luas, lebih efektif, dan efisien

\section{Daftar Pustaka}

Barret, E dan Curtis, L.F., 1992, Introduction to Environmental Remote Sensing, Third Edition, Chipman \& Hall, Madras.

Danoedoro, Projo, 1996, Pengolahan Citra Digital,

Teori dan Aplikasinya dalam Bidang Penginderaan Jauh, Fakultas Geografi, Universitas gadjah Mada, Yogyakarta.

Hardjo, K.S., 2005, Modul Praktikum Sistem Informasi

Geografi Berbasis Vektor, Fakultas Geografi, Universitas gadjah Mada, Yogyakarta.

Kementerian Kebudayaan dan Pariwisata Republik Indonesia, 2010, Kajian Manajemen Terpadu Kawasan Borobudur, Jakarta. (tidak dipublikasikan).

Lillesand, T.M and Kiefer, R.W., 1979, Penginderaan Jauh dan Interpretasi Citra, (terjemahan), Yogyakarta: Gadjah Mada University Press.

Malingreau, J.P., 1978, Penggunaan Lahan Pedesaan

Penafsiran Citra untuk Inventarisasi dan Analisisnya, PUSPICS UGM-Bakosurtanal, Yogyakarta.

Peraturan Pemerintah No. 16 Tahun 2004 tentang Penatagunaan Tanah.

PMNA/Ka.BPN No. 1 Tahun 1997 tentang Pemetaan Penggunaan Tanah Pedesaan.

Sutanto, 1994, Penginderaan Jauh Jilid 1 \& 2, Yogyakarta: Gadjah Mada University Press.

Tanudirjo, D.A., 2008, Master plan Kawasan Candi dibandingkan dengan pemetaan terestrial.

2. Di Kawasan Strategis Nasional Borobudur, citra hasil 'capture' dari Google Maps dapat digunakan untuk pemetaan tematik skala menengah (skala 1:10.000) menggunakan metode interpretasi visual dengan kualitas yang cukup baik, ditunjukkan dengan hasil uji ketelitian interpretasi yang mencapai 91,54\%.

3. Pengetahuan interpreter tentang daerah yang dipetakan memegang peranan penting dan sangat mempengaruhi hasil ketelitian interpretasi, terutama pada obyek-obyek yang penggunaan lahannya berbeda tetapi mempunyai karakteristik sama atau hampir sama pada citra.

4. Lima penggunaan lahan terluas di KSN Borobudur adalah sawah $(32,93 \%)$, kebun $(24,18 \%)$, permukiman $(24,81 \%)$, tegalan $(12,17 \%)$, dan lahan terbuka $(4,57 \%)$.

5. Perubahan penggunaan lahan dari lahan tidak terbangun menjadi lahan terbangun cukup banyak terjadi di KSN Borobudur, sehingga membutuhkan pengawasan dan pengendalian sesuai dengan undangundang yang berlaku.

Borobudur, Expert Meeting, tentang Strategi Pelestarian dan Pemanfaatan Candi Borobudur 25 Tahun Pasca-

Pemugaran, Magelang, Indonesia.

Tanudirjo, D.A., 2008, Penataan Ruang Kawasan Cagar

Budaya Candi Borobudur, Workshop, Departemen

Kebudayaan dan Pariwisata bekerjasama dengan

Departemen Pekerjaan Umum, Jakarta.

Undang-undang Republik Indonesia Nomor 11 Tahun

2010 tentang Cagar Budaya.

Undang-undang Republik Indonesia No. 26 Tahun 2007 tentang Penataan Ruang

Wibowo, P.E., 2010, Identifikasi Perubahan Tutupan

Lahan Pulau Panggang, Pulau Pramuka, dan Pulau

Karya Antara Tahun 2004 dan tahun 2008, Tugas Akhir,

Fakultas Ilmu dan Teknologi Kebumian, Institut

Teknologi Bandung, Bandung.

Wijaya, RNH, 1999, Modul ER Mapper, Volume 1,

Risky's Digital Image Processing Laboratory, Yogyakarta. 